\title{
Teaching Academic English Corpus Trough Word-formation
}

Irina B. Korotkina - Dr. Sci. (Education), Assoc. Prof., Director of Academic Writing and Communication Center, Dean of Interdisciplinary Department of English, e -mail: irina.korotkina@gmail.com Russian Presidential Academy of National Economy and Public Administration, Moscow, Russia Address: 82, bldg. 1, prosp. Vernadskogo, 119571, Moscow, Russian Federation Moscow School of Social and Economic Sciences, Moscow, Russia Address: 82, bldg. 2, prosp. Vernadskogo, 119571, Moscow, Russian Federation

Abstract. Classical elements permeate global academic discourse and scientific terminology. Understanding the meanings and functioning of these elements can help multilingual scholars cope with disciplinary literature and write for publication and is therefore essential in teaching English for academic and specific purposes. However, few manuals on academic vocabulary explore word-formation in-depth or use it as a tool to alleviate learning through analysis and synthesis rather than memorizing words. Russian, as many other European languages, is a synthetic language in which affixation is as productive as in Latin. The paper presents a well-designed and approbated course of academic vocabulary for social scientists, analyses relationships between linguistic studies and teaching academic vocabulary, and discusses the ways of increasing the effectiveness and clarity of teaching by more systematic study of classical elements, enhancing students' analytical skills through innovative methodology and using the advantages of similarities between Russian and Latin word-formation. Comparative analysis demonstrates that the key features of the course, such as interactive computer-based visual materials and various analytical tasks involving students' background knowledge and academic awareness, help students not only decipher unknown words, but also produce neologisms, which is essential in coping with new terminology. Published as a book, Academic Vocabulary for Social Sciences is now available for teachers, students and researchers as a resource for study and self-study. The effectiveness of the approach demonstrates that it can be used as a model to design similar specific vocabulary courses for students of other synthetic languages.

Keywords: academic vocabulary, word-formation, classical elements, affixation, academic writing, English for academic purposes, academic discourse

Cite as: Korotkina, I.B. (2019). Teaching Academic English Corpus Trough Word-formation. Vysshee obrazovanie v Rossii = Higher Education in Russia. Vol. 28. No. 2, pp. 94-103. (In Russ., abstract in Eng.)

DOI: https://doi.org/10.31992/0869-3617-2019-28-2-94-103

\section{Introduction}

English is commonly accepted today as the lingua franca of scientific and academic communication; however, it has a relatively short history. Until the end of the $19^{\text {th }}$ century this role was played by Latin, and terminology in most disciplines, as well as the lexis more generally used in academic discourse, still contain elements from classical languages. Latin actively used in English is a paradox, for the former is a synthetic language with a very high morphemeper-word ratio, whereas the latter is perfectly analytic. Despite the fact that the heritage of Latin words in modern English reaches 70 per cent - and even more in scholarly publications - native speakers are not used to wordformation by affixation. Because of this, students and researchers encounter difficulties in 
coping with long complicated lexemes, difficult to spell and pronounce, and sometimes hard to decode.

Word-formation based on classical and neoclassical elements in English is therefore an important issue for the international academic community, teachers of academic English (especially writing) and authors of manuals on academic vocabulary. As it is essential to learn and use classical elements, word-formation should be properly studied and presented as a clear and easy-to-use systematic framework. Although word-formation is not regarded as having one unified doctrine [1], the study of morphemes took precedence over the study of words after Naom Chomsky's famous work [2], which led to considering word parts as more important in forming meaning of whole sentences. For instance, Adams in her book [1] focuses on "meanings and how they are expressed and combined", emphasizing the possible interrelations between traditional patterns of word-formation. Latin affixation and multiple roots from classical languages (both Greek and Latin) are productively used in English and other European languages to form disciplinary terminology, web neologisms and academic vocabulary in general $[3 ; 4]$.

The prevalence of regularity of how new meanings are formed in academic vocabulary and terminology makes word-formation equally attractive to linguists and teachers of academic English and other languages. Indeed, when Latin adoptions are considered, irregularities appear insignificant in comparison with the great productivity of affixes and even some roots. For instance, among the many adjectives derived from the Latin root 'duct' with the suffix '-ive' (deductive, productive, seductive, conductive, etc.) only one, 'introductory', is formed with '-ory'; consequentially, the adverb 'introductorily' falls out of the regular pattern as well. The root forms a perfect list of regular nouns with '-ion' (introduction, deduction, abduction, reduction, conduction, subduction etc.), meaning 'process', and a regular - although shorter due to the nonoccurrence of some words - list of nouns with '-er' (producer, introducer, seducer, etc.).
While linguists are still arguing about the theoretical issues in word-formation, the debatable but useful and transparent term 'combining form' [4-6] is more and more widely used in dictionaries. For example, the Oxford English Dictionary applies it to classical and neoclassical (formed in modern academic context) elements given with a hyphen (e.g. - graph, photo-, bydro-). As English speakers today do not use affixation, they tend to generally ignore the distinctions between different elements, and dictionaries sometimes present the same element in combination with different affixes, such as -grapher, -ography, or in their different representations, such as bistorio- (Latin) and bistorico- (Greek).

However, rapid global developments in science and technology urge researchers to use one common language of academic discourse which ought to be understood internationally and therefore taught in a most comprehensive and easy-to-use way. In this paper, I will discuss the possible ways of interaction between researchers in linguistics and English for academic and specific purposes under the umbrella of academic literacy. The paper will present the analysis of how word-formation is treated in academic vocabulary manuals. Publication of the most effective books helping students cope with Latin and Greek elements will be viewed in close connection with developments in academic writing. Russian research, although scarce, will also be discussed; moreover, as both Russian and Latin use common word-formation through affixation, these common features can be utilized for direct and explicit teaching academic words of classical origin to Russian students. The prospects and effectiveness of such an approach are supported by the recently published book Academic Vocabulary for Social Sciences [7].

\section{Word-formation in teaching English and Russian for Academic Purposes}

Defining productive affixes and roots in dictionaries is not the only practical outcome that calls for clarity; a much more effective way to help researchers and students is to develop ana- 
lytic skills that will enable them to recognize and actively use complex lexemes produced from classical and neoclassical combining forms. Menzel and Degaetano-Ortlieb [4, p. 189] conclude that " $[\mathrm{m}]$ orphological awareness, the skill to analyse internal structures of complex words and to understand morphological rules of the native languages, is a comprehension and language production skill that has to be acquired by language users along with other linguistic skills".

Developing analytic language skills is the domain of academic literacy, which 'involves higher-order thinking - decoding, conceptualizing, inferring, inventing, and testing' [8, p. 10]. These skills are central in education, and should permeate academic language teaching methodology, evincing motivation in students to discover 'regular features of academic English that are well defined and teachable' [Ibid]. If word-formation is well defined, it will (and it practically has) become quite teachable.

The key components of academic literacy are academic writing and reading because the medium of academic communication is a written (published) text. Accordingly, Western universities stipulate that academic literacy be their institutional obligation, and writing be considered central, or fundamental, set of competences obtained in higher education $[9 ; 10]$. The two main approaches to teaching English at university are English for academic purposes (EAP) and English for Specific Purposes (ESP). In teaching EAP, academic vocabulary is essential, whereas in teaching ESP, terminology. Both the English academic vocabulary and terminology within disciplines are formed mainly from classical and neoclassical elements, but academic vocabulary is used across disciplines, which makes it essential for all researchers and therefore more important to learn. It is the proper use of academic vocabulary that distinguishes scholarly publications.

Academic writing skills are therefore crucial for disciplinary and academic discourse [9; 11], and as English has become the lingua franca in sciences, mastering writing (or at least read- ing) in this language is essential today for all researchers. The problems faced by multilingual scholars in mastering academic discourse in English is now the focus of specific research [12-14]. As more nations join international publishing, a new branch of English for Research Publication Purposes arises as a methodology of teaching academics and scholars [12], and Russia is one of the countries that needs to develop this methodology [15].

Teaching researchers logically involves coping with word-formation based on classical and neoclassical elements. Written English is significantly different from spoken English, and if the general English corpus is believed to contain around 70 per cent of words of Latin origin, scholarly papers contain more; some pages can be written totally in words and terms consisting of classical elements except for articles, prepositions and figures. This makes the study of these elements especially important for university students and becomes a matter of concern not only for linguists, but also teachers of English and authors of textbooks and manuals.

Despite its obvious importance, classical word-formation is generally neglected in EAP books. Academic vocabulary manuals are typically viewed as supplementary materials for developing other academic skills, reading and writing above all [e.g. 16], or preparing students for international tests and exams, such as SAT, IELTS, or TOEFL. Most academic vocabulary manuals are aimed at self-study, and present words in random sets united by either a common topic or linguistic features (e.g. collocations, word class, spelling, etc.), or both. EAP books also include reference materials and appendices, and it is usually there that information about word-formation can be found. Within a book, word elements occur occasionally, for instance, as a table to be completed with derivatives.

Such resources do not give any systematic explanations and sometimes appear confusing. For instance, Latin prefixes, such as $e x-$, de-, in-, or pre-, are confused with roots, such as semi, quasi, pseudo, mono, kilo or neo, and even with the abbreviation $e$-for electronic [16, 
p. 128-131]. In this logic, the combining form anthropo- should also be considered a prefix just because there are words antbropology, anthropomorphic, and anthropometric. As a result, students get a much longer list of 'prefixes' than necessary and either do not understand what a prefix is (in case of speakers of analytic languages) or get puzzled (in case of speakers of synthetic languages with a high morpheme-perword ratio, like Russian).

The uncertainty among linguists and lexicographers in making distinctions between affixes and combining forms cannot be an excuse for authors of academic vocabulary manuals to confuse affixes with roots so carelessly. These distinctions are discussed in textbooks for students whose subject is lexicography or linguistics $[1 ; 3]$, but a detailed linguistic analysis is not the subject of EAP. Authors of manuals published by international publishers should make things clear and explicit for students of non-linguistic disciplines. This may involve simplifications and generalizations, but never ambiguity or confusion of a well-established science.

Latin prefixes in academic vocabulary manuals should and can be made clear to students. They have only grammatical meaning, and they are few: their list is as short as the list of English prepositions - or rather postpositions, which play the same role in English and are commonly used to explain the meanings of Latin prefixes (e.g. destroy - pull down, compose - put together, repell - drive back, insert - fill in, etc.) in books for non-linguistic students [e.g. 17-20]. If prefixes are not confused with Greek elements, such as meta-, quasi- or peri-, or roots, such as mini-, neo- or milli-, they can be given on one page with all necessary examples and definitions.

The confusion of prefixes with other elements may result not from ignorance (which is hard to believe), but other reasons: first, EAP manuals are addressed to international students with various languages, some of which have no idea of word-formation at all; secondly, distinctions between affixes and roots may seem insignificant for native speakers of English because the English language is analytic with a very low morpheme-per-word ratio. The functioning of Latin prefixes in English is mostly limited to words of classical origin, although the frequency of some of them leads to acceptance and paradoxical occurrence in 'native' English words (e.g. remake, discharge, precooked), which is noted by some Russian researchers [21, p. 180]. This acceptance by native speakers, however, does not imply that English is becoming more synthetic: the opposite example is the use of a prefix as a separate word - quite naturally for English - prepped (a passive form generalizing verbs with pre-).

For speakers of Russian and other synthetic languages, confusion of prefixes and roots appears strange. Russian word-formation is much closer to Latin, and this similarity gives Russian students an advantage to boost their English academic vocabulary by building direct correspondences between Russian and Latin prefixes. Moreover, there are also Latin suffixes with their grammatical meaning (which is not only word class distinctions), a few similar roots (e.g. vert-Bepm, turn; vid-Bud, see; oc-ox/ou, eye; sid-cud, sit; $i-u(u \partial$, go), and a considerable number of words containing classical and neoclassical elements adopted from European languages (although they are not as multiple and regular as in English). If we find a key to open classical elements for students and discover hidden regularities and correspondences, then academic words, scientific terms and probably the 70 per cent of the English corpus will open for us without a dictionary.

Unfortunately, Russian research on the subject is scarce. There are, of course, books on English lexicology and lexicography for philological faculties - more than 50 can be found on eLibrary.ru with 'English lexicology' in the title. Some of them are brief and have poor bibliography, which includes a few English dictionaries and previous books by Russian authors, others comprehensive with a wide range of references to international linguistic literature. However, even comprehensive and wellsupported books avoid classical elements in 
chapters on English word-formation [22]. This fault may be partially explained by the fact that virtually all Russian lexicologists and linguists refer to classical English or American literature instead of academic texts or at least up-to-date press or media, which is due to the traditional connection of language with literature, lack of academic writing in the Russian education and probably the problem of copyright.

Articles on word-formation typically involve comparative studies with ethnic languages or particular contexts (English and American literature, sports, economics, slang, neologisms, media, etc.). Few discuss classical and neoclassical elements in English and Russian, most of them written by ESP teachers, particularly in medical science [23-25]. Researchers provide lists of classical affixes with Russian definitions or compare them with English affixes. Sadly, Russian researchers disregard the obvious correspondence between Latin and Russian prefixes, but follow the English tradition and explain their meanings in words, partially with prepositions, for instance [23, p. 78]:

con - 24 записи со значением совместности, соединения, e.g. condominium - кондоминиум. Образуются в основном имена существительные.

pre - 32 записи со значением перед, до, предварительно предшествование во времени е.g., prehistoric - доисторический, prerecorded - записанный заранее. Образуются имена прилагательные.

The authors indicate the number of occurrences of the prefixes in the Webster's Revised Unabridged English Dictionary. Without discussing the figures, it is hard to agree with the authors' conclusion that the prefix con-is mostly used with nouns, and pre- with adjectives: in figures, probably, but never in the logic of derivation. Prefixes generally precede verbs in synthetic languages, and Latin is no exception. Prefixated nouns are typically derivatives from prefixated verbs, and adjectives from nouns. The prefix con- is clearly and precisely explained by the corresponding Russian prefix co-/c- (conduct conровождать, compose- составлять, со- чинять, collect - coбирать, concede - coглашаться, connect - соединять, etc.), and preby nред- (predict - nредсказьıать, present представлять, рrеsите - предполагать, precede - nредшествовать, preside - nредседательствовать). The two prefixes even look (or sound) similar with Russian prefixes, and any Russian speaker immediately grasps the similarity without extra explanations (an even more prompting similarity appears in the prefix pro-: e.g. propulse - nроталкивать, providenровидеть, promote - продвигать, produce nроизводить). Derivatives can be multiple (e.g. conduction, conductive, conductor, conductivity, misconduct; presentation, presenter, presentable, representative, representability), but the prefix keeps its meaning even when another prefix is attached (which is also initially attached to the already prefixated verb: mis-conduct, re-present). In Russian, two or even three prefixes per word is as common as in Latin (BoCnро-извести, виь-nро-bодить; con-de-scend, re-pro-duce, de-con-struct, co-ex-ist, etc.). Occurrence in dictionaries is not always the proper method in linguistics to judge the semantics of word-formation.

Another common drawback is that Russian authors also include Greek elements or lexemes with non-grammatical meaning into their lists of prefixes, e.g. dys-, meta- [24, p. 89], bi-, meta-, multi-, semi-, micro-, vice-, mini-, milli- [23, p. 78-80]. In other papers, Latin prefixes are often mixed up with both lexical elements and English prefixes (un-, be-, over-, under-, etc.) with examples from $19^{\text {th }}$ century literature.

Despite the scarcity of publications or poor quality of some papers (not referred to in this paper for understandable reasons), Russian researchers agree that word-formation from classical elements plays an important role in the lexicon of scientific discourse. Researchers from medical universities consider the study of Latin essential in students' not only professional, but also academic and cultural development. Similar ideas are sometimes expressed by teachers of English for law. Medicine and law are the two disciplines in which the Latin language is incor- 
porated into disciplinary programmes. S. Yanutik argues that Latin affixation is becoming more and more productive in modern English, and involves not only academy, but also everyday communication. A few papers discuss Latin as the language of scientific communication with references to its heritage and Neo-Latin Studies [25]; these papers do not directly discuss word-formation but emphasize the influence of the classical language on today's scientific discourse. Notably, I. Zubenko and I. Masneva [24, p. 87] conclude that "the analysis of unknown words by word-forming elements provides a rational way to learn to understand scientific text $<\ldots .>$ in English without a dictionary". Two thumbs up.

\section{The analytic approach to mastering} word-formation from classical elements

In fact, books applying analytic skills to classical elements have existed for half a century and are widely available today in the USA. They "help students improve their mastery of the English language and acquire the keys for understanding thousands of words by studying Greek and Latin word parts (prefixes, root words, and suffixes)" [18]. Nothing is uncertain in them, and some are even addressed to primary school children [e.g. 19]. The history - or rather a story - of these books is remarkable, and behind the story (more implied than clearly seen to those unconcerned) stands academic writing.

The story begins in 1965 with two books published simultaneously: Harold Levine's Vocabulary for College-Bound Student [26] and Donald Ayers's English Words from Latin and Greek elements [17]. The edition of Ayers's book was completed and published by his disciples after the author's demise. Both authors were experts in classical languages, and both books are still issued and widely used. In both books, word elements are classified, their meanings explained, and explanations supported with exercises. Two years later Levine issued a workbook, and later both books appeared in new editions in co-authorship with Norman and Robert Levine [21]. Levine's book is much more user-friendly than Ayers's, and although from the point of view of modern language teaching methodology both books are outdated, Levine's approach was revolutionary, as it includes not only gap-filling exercises, but also matching synonyms, antonyms and analogies. These activities along with the systematic approach involve students in analytic, higher-order thinking essential for academic literacy.

The demand for the books was due to the development of academic writing in the US, which had accumulated a considerable potential by the 1960s to influence the US higher education. Academic essays became compulsory, and the Scholastic Assessment Test (SAT) was obligatory in many colleges. The SAT preparation includes testing academic vocabulary skills: that is the area where young native speakers of English get at a loss because of the prevalence of Latin and Greek elements and uncommon word-formation with difficult to spell and pronounce complicated lexical structures. With the SAT gaining more and more momentum, entertaining books for schoolchildren started to appear [18; 19], as well as multiple flashcards and games with Latin and Greek word elements on the web.

Academic writing in Russia is still a novelty, and teaching language, Russian or English, is still connected with literature rather than non-fiction. As students do not develop academic writing skills systematically, university graduates and researchers often are incapable of meeting the requirements of international publications. Apart from wordiness, nominalization and incomprehensive syntax, their papers mix up spoken and written registers, and use insufficient or irrelevant academic vocabulary.

The idea of developing a course focused on classical and neoclassical elements occurred to me in 2000, when I first encountered Levine's book. The ESAP course of Academic Vocabulary for Social Sciences took several years to design to meet the needs of Russian master's degree students of the MSSES, which is a Russian-British university and create activities in accordance with modern ESAP methodology. 
The most important feature of the course was bridging Russian word-formation with Latin, and spelling habits with Greek. Ways of coping with Latin prefixes were partially mentioned above, but the problems of coping with Greek are a special issue. Russian Cyrillic tradition of spelling Greek words can be divided into two periods, roughly before Peter I, when words were taken directly from Greek, and after, when scientific terms started to come from Western Europe in Latin. Because of that we spell, for instance, the Greek beta and theta differently in older and later adoptions, e.g. mythology, orthography, but theory, orthodox; Thebes, Babylon, but bibliography, etc. There are other peculiarities of spelling, but also of stress in Greek words. All these were used in entertaining activities, including ICT with the use of colour, image and animation, individual and group analytic activities, etc.

The activities involved higher and higher order of intellectual work according to the approach we use at the MSSES Department of Academic English - the evolving uprising spiral of skills development. An important component of the course was the systematic approach. For instance, it is easier to cope with words of classical origin keeping in mind the distinction in usage. Greek word-formation is typical in natural sciences and technology, philosophy and philology, whereas Latin is used in social sciences and more generally, in academic vocabulary for communication. The obvious prevalence of Latin is clearly seen through activities on 'translating' Latin words into Greek and vice versa (e.g. aquatic (sports) - bydraulic (mechanics), multicoloured (fasbion) - polychromatic (optics), contemporary (society) - synchronous (physics), Subterranea (for social activities) bypogeum (in archaeology or biology).

The course was successful with MSSES students, and later with $\mathrm{PhD}$ students, teachers and professors of the National Research University Higher School of Economics, where I give seminars at the Academic Writing Center. Eventually, the course was developed into a book and published [7]. The book is organized systemati- cally and applies the evolving uprising spiral approach by a variety on non-repetitive activities involving analysis and synthesis, comparison and analogies, decoding and inferring. The Student's Book is in English, but all the explanations and references are given along with keys in the Teacher's Book (under the same cover for selfstudy purposes). The interactive slides are found on the Publishers' website and the author's personal website.

\section{Conclusion}

The issues of linguistic theory concerning modern English word-formation are inseparable from the functioning of the language in today's global academic communication. Scientific terminology and the lexis used in scholarly publications, which are mainly written in English, traditionally contain more Latin and Greek elements than spoken English. Terminology is mainly formed of classical and neoclassical combining forms, producing complicated lexical structures with difficult spelling and pronunciation; these structures are subject to change as disciplines develop, and are used by professionals in disciplines. Academic vocabulary is formed of Latin elements with active affixation and is generally steadier; however, it is used across disciplines and is therefore essential in international academic and scientific discourse and ought to be learned and properly used by researchers. Despite its analytic typology, English has inherited Latin affixation and multiple derivatives which tend to permeate modern English and are accepted by native speakers. This makes the study of classical and neoclassical elements in English word-formation crucial both for linguists and lexicographers, and for EAP and ESP researchers.

Developments in the field can help researchers around the world improve their writing and reading skills in English. Aiming at clarity and logic rather than terminological precision, theorists may contribute to practical outcomes, such as convenient labeling of classical elements in dictionaries, or assisting authors in EAP with 
guidance concerning linguistic relevance and consistency. Modern developments in EAP and ESP methodology provide good basis for explicit and effective teaching in the framework of academic literacy. Languages differ in typology, but non-native teachers of EAP and ESP should think wider and employ interdisciplinary approaches to meet the needs of the global academic community. The book Academic Vocabulary for Social Sciences [7] is just one example of effective merging of linguistic and ESAP methodology in meeting the needs of future scientists and multilingual scholars today. The approach used in the book can be further developed to design courses in ESP and English for Research Publication Purposes. Due to the international use of classical elements and the synthetic structure of many other languages, it can serve as a model to design academic vocabulary courses in other linguistic contexts and educational settings.

\section{References / Иитература}

1. Adams, V. (2013). An Introduction to Modern English Word-formation. London: Routledge: Taylor and Francis Group.

2. Chomsky, N. (1957). Syntactic Structures. The Hague: Mouton. $118 \mathrm{p}$.

3. Green, T.M. (2015). The Greek and Latin Roots of English. $5^{\text {th }}$ ed. Lanham: Rowman \& Littlefield. $304 \mathrm{p}$.

4. Menzel, K., Degaetano-Ortlieb, S. (2017). The diachronic development of combining forms in scientific writing. Lege Artis: Language Yesterday, Today, Tomorrow. Vol. II, no. 2, pp. 185-249.

5. Kastovsky, D. (2009). Astronaut, astrology, astrophysics: About combining forms, classical compounds and affixoids. In: Selected Proceedings of the 2008 Symposium on New Approaches in English Historical Lexis (HEL-LEX), Lammi, Finland, 25-28 April 2008. Pp. 1-13.

6. Hacken, P., Panocová, R. (2014). Neoclassical formatives in dictionaries. In: Proceeding of the $16^{\text {th }}$ EURALEX International Congress, Bolzano, Italy, 15-19 July, 2014. Pp. 1059-1072.

7. Korotkina, I.B. (2016). Academic Vocabulary for Social Sciences. Moscow: HSE Publishing House. $301 \mathrm{p}$.
8. Scarcella, R. (2003). Academic English: A Conceptual Framework. Technical Reports, University of California Linguistic Minority Research Institute, UC Berkeley. Available at: http://escholarship.org/uc/item/6pd082d4 (Accessed 9 January 2018).

9. Hyland, K. (2016). Teaching and Researcbing Writing. New York and London: Routledge, $314 \mathrm{p}$.

10. Murray, N., Kirton, B. (2006). An Analysis of the Current Situation. In: S. Davies, D. Swinburne and G. Williams (Eds.) Writing Matters: The Royal Literary Fund Report on Student Writing in Higher Education. London: The Royal Literary Fund. Pp. 7-13.

11. Hyland, K. (2000). Disciplinary Discourses: Social Interactions in Academic Writing. London, Longman. $232 \mathrm{p}$.

12. Flowerdew, J. (2013). English for research publication purposes. In: B. Paltridge, S. Starfield (Eds). The handbook of English for specific purposes. Malden, MA: Wiley-Blackwell. Pp. 301-321.

13. Cargill, M., Burgess, S. (Eds.) (2017). Publishing Research in English as an Additional Language: Practices, Pathways and Potentials. University of Adelaide Press. 277 p.

14. Lillis, T., Curry, M.J. (2015). The politics of English, language and uptake. AILA Review, Vol. 28. P. 127-150. Available at: https://benjamins. com/catalog/aila.28.06lil/fulltext/aila.28.06lil. pdf

15. Korotkina, I.B. (2018). Russian Scholarly Publications in the Anglophone Academic Discourse: The Clash of Tyrannosaurs. Integratsiya obrazovaniya $=$ Integration of Education. Vol. 22. No. 2. Pp. 311-323.

16. McCarthy, M., O'Dell, F. (2008). Academic Vocabulary in Use. Cambridge, England: Cambridge University Press. $176 \mathrm{p}$.

17. Ayers, D.M. (1986). English Words from Latin and Greek elements. University of Arizona Press. $290 \mathrm{p}$.

18. Draze, D. (2005). Red Hot Root Words: Mastering Vocabulary with Prefixes, Suffixes and Root Words (Book 2). Prufrock Press. 68 p.

19. Callella, T. (2004). The Learning Works: Prefixes and Suffixes, Grades 4-8: Teaching Vocabulary to Improve Reading Comprehension. Creative Teaching Press. $144 \mathrm{p}$.

20. Levine, H., Levine, N., Levine, R. (2003). Vocabulary for the College Bound Student. $4^{\text {th }}$ edition. Amsco School Publications. 340 p. 
21. Янутик C.Я. Аатинские аффиксы в системе знаменательных частей речи английского языка // Филологические науки. Вопросы теории и практики. 2016. № 2-1 (56). С. 178180 [Yanutik, S.Y. (2016). Latin Affixes in the System of Nominal Parts of Speech of the English Language. Filologicheskie nauki. Voprosy teorii $i$ praktiki $=$ Philological Sciences. Issues of Theory and Practice, No. 2-1 (56). Pp. 178-180 (In Russ., abstract in Eng.)]

22. Гвишиани Н.B. Современный английский язык: Иексикология. М.: Академия, 2009. 221 c. [Gvishiani, N.B. (2009). Modern English Lexicology: Vocabulary in Use. Moscow: Akademiya Publ. 221 p. (In Russ.)]

23. Янутик С.Я., Алатов А.М. Словообразовательный потенциал префиксов латинского происхождения // Научные ведомости Белгородского государственного университета. Серия: Гуманитарные науки. 2017. Т. 34. № 14 (263). C. 76-83 [Yanutik, S.Y., Amatov, A.M. (2017). Derivational Potential in Prefixes of Latin Origin. Nauchniye Vedomosti Belgorodskogo gosudarstvennogo universiteta. Seriya Gumani- tarnye nauki $=$ Belgorod State Univ. Scientific Bulletin. Humanities Sciences. Vol. 34. No. 14 (263). Pp. 76-83 (In Russ., abstract in Eng.)]

24. Зубенко И.В., Маснева И.Е. Морфемное словообразование в латинском и английском языках // Язык и культура. 2002.№ 2. С. 86-90 [Zubenko, I.V., Masneva, I.E. (2002). Morphemic Word-formation in Latin and English. Yazyk $i$ Kul'tura $=$ Language and Culture. No. 2. Pp. 86-90. (In Russ.)]

25. Кондратьељ А.К. Аатынь в современном мире // Журнал Гродненского государственного медицинского университета. 2007. № 4. C. 170-173 [Kondratyev, D.K. (2007). Latin in the modern world. Zburnal Grodnenskogo gosudarstvennogo meditsinskogo universitet $a=$ Journal of the Grodno State Medical University. No. 4. Pp. 170-173. (In Russ.)]

26. Levine, H. (1965). Vocabulary for the College Bound Student. Amsco School Publications. $320 \mathrm{p}$.

The paper was submitted 25.12.18 Accepted for publication 14.01.18

\section{Обучение англоязычной научной лексике через словообразование}

Короткина Ирина Борисовна - А-р пед. наук, доцент, директор центра академического письма и коммуникации, зав. межфакультетской кафедрой английского языка. E-mail: irina.korotkina@gmail.com

Российская академия народного хозяйства и государственной службы при Президенте РФ, Москва, Россия

Адрес: 119571, г. Москва, просп. Вернадского, 82, стр. 1

Московская высшая школа социальных и экономических наук, Москва, Россия

Адрес: 119571, Москва, просп. Вернадского, 82, корп. 2

Аннотация. Основу терминологии разлиньх дисчиплин и общенаучной лексики составляют слова, образованнье из элементов латинско-греческого происхождения. Понимание значений этих элементов и умение их использовать в работе с текстами на англииском языке и подготовке публикачий в международных журналах жизненно необходимо каждому исследователю и, соответственно, каждому студенту, ориентированному на науку. $B$ статье представлен подход к обучению академической лексике через анализ и синтез классических элементов. Опираясь на компаративный анализ существуюших методических подходов и хорошо апробированный в практике высшего и постдипломного образования авторский подход к обучению академической англоязычной лексике, автор показыьает эффективность такого подхода и обосновывает место специализированного курса по академической лексике в программе англииского языка для академических чјелей вуза. Основньми характеристиками курса являются интерактивньй подход с использованием визуальньх 
возможностей ИКТ и расширение лексического запаса без опоры на память через аналитические компетениии с задействованием фоновьх, научных и общекультурных знаний обучающихся, а также использование типологического сходства латинского и русского словообразования. Курс был опубликован как учебное пособие "Академическая лексика сочиальных дисчиплин» В 2015 2. и в этом качестве может и уже используется как в аудиторной работе со студентами, так и самостоятельно, особенно в ходе подготовки исследователем научной статьи на английском языке. Трансдисчиплинарный характер учебного пособия, ориентированного на общий для всех научных отраслей корпус научной лексики, делает его полезным для спечиалистов различного профиля.

Ключевые слова: английский дл академически челей, академическая лексика, терминообразование, язык научного текста, словообразование в англииском языке, латинско-греческие заимствования

Аля цитированил:Korotkina I.B. Teaching Academic English Corpus Trough Word-formation // Высшее образование в России. 2019. Т. 28. № 2. С. 94-103.

DOI: https://doi.org/10.31992/0869-3617-2019-28-2-94-103

Статья поступила в редакиию 25.12.18

Принята к публикачии 14.01.18

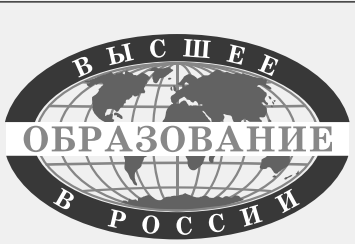

Дорогие друзья!

Подписная кампания на 2019 год благодаря вашей поддержке в целом проходит успешно. Спасибо всем за доверие!

«Роспечать». Индексы: 73060, 82521

«Пресса России». Индексы: 16392, 83142 ООО «Урал-Пресс» - тел.: (495) 789-8636 